\title{
Удосконалення швидкісних якостей плавців 13-14 років шляхом підвищення ефективності креатинфосфатного механізму енергозабезпечення м'язової роботи
}

\author{
УДК 796.015.53.574:797.21.077.5-053.66 \\ Ю. М. Фурман ${ }^{1}$, М. О. Бойко1, І. В. Грузевич², \\ М. Л. Слободянюк
}

${ }^{1}$ Вінницький державний педагогічний університет імені Михайла Коцюбинського,
Вінниця, Україна
${ }^{2}$ Київський національний університет технологій і дизайну, Київ, Україна
${ }^{3}$ Національний університет фізичного виховання і спорту України, Київ, Україна

Резюме. Мета. Науково обґрунтувати доцільність серійного застосування спринтерських навантажень для підвищення потужності анаеробних алактатних процесів енергозабезпечення плавців на етапі їх попередньої базової підготовки. Методи. Теоретичний аналіз і узагальнення літературних джерел, що розкривають фізіологічний механізм швидкісних можливостей спортсмена. Дослідження потужності анаеробної алактатної і лактатної продуктивності, а також потужності аеробних процесів енергозабезпечення спортсменів і спеціальної фізичної підготовленості плавців. Результати. Аналіз науково-методичних джерел дозволив охарактеризувати медико-біологічні чинники, які впливають на швидкісні можливості спортсменів. На прикладі плавців 13-14 років встановлено, що підвищити швидкість можна за рахунок вдосконалення креатинфосфатного механізму енергозабезпечення м'язової роботи. Для цього в тренуваннях слід серійно застосовувати спринтерські навантаження. Запропоновано методику кількісного дозування спринтерської роботи, яка виконується в алактатному режимі енергозабезпечення. Узагальнення науково-методичної інформації свідчить про наявність двох груп морфофункціональних чинників, які визначають швидкісні можливості спортсменів. Перша - генетично детерміновані, які не піддаються вдосконаленню. Друга - чинники, які вдосконалюються за допомогою фізичних вправ, зокрема шляхом серійного виконання спринтерських навантажень тривалістю до 10 с кожне з інтервалом відпочинку між ними близько 2 хв та інтервалом між серіями 10-15 хв.

Ключові слова: швидкість, медико-біологічні механізми удосконалення швидкості, анаеробна алактатна продуктивність, спринтерські навантаження.

Improving the speed of swimmers aged 13-14 years by increasing the efficiency of the creatine phosphate mechanism of muscular work energy supply

Yu. M. Furman', M. O. Boyko', I. V. Hruzevych², M. L. Slobodyanyuk ${ }^{3}$

${ }^{1}$ Vinnytsia Mykhailo Kotsiubynskyi State Pedagogical University, Vinnytsia, Ukraine

${ }^{2}$ Kyiv National University of Technologies and Design, Kyiv, Ukraine

${ }^{3}$ National University of Physical Education and Sport of Ukraine, Kyiv, Ukraine

Abstract. Objective. To scientifically substantiate the expediency of using sprint loads to increase the power of anaerobic alactate processes of energy supply of swimmers at the stage of preliminary basic training. Methods. Theoretical analysis and synthesis of literary sources that reveal the physiological mechanism of high-speed capacities of an athlete. Investigation of the power of anaerobic alactate and lactate productivity, as well as the capacity of aerobic processes of energy supply and special physical fitness of athletes. Results. The analysis of scientific and methodological sources allowed to characterize the medical and biological factors that affect the speed of athletes. The example of swimmers aged 13-14 shows that the speed can be increased by improving the 
creatine phosphate mechanism of muscle work energy supply. For this purpose sprint loads should be serially applied in training sessions. A method of quantitative dosing of sprint work, which is performed in the lactate mode of energy supply, is proposed. The generalization of scientific and methodological information indicates the presence of two groups of morphofunctional factors that determine the speed capabilities of athletes. The first is genetically determined, which is not improved. The second - factors that are improved through exercise, in particular, by serial execution of sprint loads lasting up to $10 \mathrm{~s}$ each with an interval of rest between them of about 2 minutes with an interval between series of 10-15 minutes.

Keywords: speed, medico-biological mechanisms of speed improvement, anaerobic lactate productivity, sprint loads.

Постановка проблеми. Аналіз змісту навчальних програм з плавання для дитячо-юнацьких спортивних шкіл олімпійського резерву, шкіл вищої спортивної майстерності [8] свідчить про те, що на етапі попередньої базової підготовки найбільше часу відведено на роботу в аеробному режимі енергозабезпечення. Робота в такому режимі не викликає функціонального перенапруження діяльності організму, однак не забезпечує належним чином підвищення швидкості. Програмою також передбачено виконання великого обсягу роботи в зоні анаеробного лактатного енергозабезпечення. Такий режим роботи підліткам дається важко і навіть може негативно вплинути на динаміку підвищення спортивних результатів $[12,13]$. Тому деякі науковці $[5,15]$ вказують на необхідність удосконалення на даному етапі спортивної підготовки швидкісних можливостей юних спортсменів, що, на наш погляд, може забезпечуватися лише шляхом виконання циклічних вправ в анаеробному алактатному режимі енергозабезпечення. На жаль, за навчальною програмою для ДЮСШ, СДЮШОР, ШВСМ на даному етапі багаторічної підготовки з усієї кількості навчальних годин лише 2-3 \% часу виділяється на розвиток анаеробних алактатних можливостей організму. Такий розподіл фрізичних навантажень за навчальною програмою не забезпечує оптимального вдосконалення швидкості плавців.

Незалежно від спортивної спеціалізації майстерність спортсмена обумовлена рівнем техніко-тактичної, психологічної, фрізичної і функціональної підготовленості. Це свідчить про те, що підготовка спортсмена повинна здійснюватися з урахуванням педагогічного (фрізична, технічна і тактична підготовка), психологічного (психічна підготовка) i медико-біологічного (підвищення функціональних можливостей організму) аспектів. На особливу увагу у фрізичній підготовці спортсмена заслуговує медико-біологічний аспект, який полягає у підвищенні функціональних можливостей тих систем організму, які забезпечують прояв характерних для окремих видів спорту якісних параметрів рухової діяльності. У тих видах спорту, де від спортсмена вимага- ється виконання роботи з максимально можливою швидкістю, особливу роль відіграють фрункціональні можливості центральної нервової системи (ЦНС), морфоофункціональний стан нервово-м'язового апарату, а також потужність анаеробних алактатних процесів енергозабезпечення м'язової роботи $[1,11]$. Коли йдеться про переміщення тіла в просторі 3 максимальною швидкістю, остання лімітується здатністю моторних центрів ЦНС активізувати максимальну кількість швидкоскоротливих (ШС) м'язових волокон, а також швидкістю і частотою поширення нервових імпульсів до цих волокон по мотонейронах. Причому фуннціональні можливості ЦНС щодо мобілізації максимальної кількості рухових одиниць, а також швидкості і частоти поширення імпульсів по мотонейронах генетично обумовлені і майже не піддаються удосконаленню [3, 22].

Для забезпечення високої швидкості рухів у різні фрази рухової дії під час виконання дистанційної роботи особливу роль відіграє здатність проявляти вибухову силу, яка залежно від спортивної спеціалізації зумовлена насамперед потужністю м'язового скорочення певних «зацікавлених» м'язових груп [1]. Наприклад, у легкоатлетичному спринті такими «зацікавленими» м'язовими групами $€$ сідничний м'яз, чотириголовий м'яз стегна, литковий м'яз, а в плаванні кролем на грудях - великий грудний м'яз, найширший м'яз спини, триголовий м'яз плеча, двоголовий м'яз стегна, чотириголовий м'яз стегна, литковий м'яз.

Слід підкреслити, що зміст понять «потужність роботи під час виконання циклічних вправ» і «потужність м'язового скорочення» різні. «Потужність роботи під час виконання циклічних вправ» відображає швидкість переміщення спортсмена по дистанції, тобто роботу, виконану за одиницю часу (в м/с), у той час як «потужність м'язового скорочення» відображає добуток сили (напруження) і швидкості скорочення м'язів. У свою чергу, сила і швидкість скорочення м'язів залежать від співвідношення в них ШС і повільноскоротливих (ПС) волокон. Співвідношення кількості ШС до ПС волокон зумовлено генетич- 
но $[18,21]$. Максимальна швидкість скорочення ШС і ПС волокон у чотири рази більша, ніж ПС волокон. Під впливом тренувань, пов'язаних 3 удосконаленням швидкості і сили, кількість ШС волокон залишається незмінною. Разом з тим тривалі заняття на розвиток витривалості сприяють збільшенню лише ПС волокон, причому за рахунок трансформації ШС волокон у ПС волокна. Підтвердженням даного френомену $\epsilon$ те, що у бігунів-спринтерів у литковому м'язі знаходиться близько $60 \%$ ШС волокон, що в 1,7 раза перевищує їх кількість у бігунів на довгі дистанції. Навпаки, у стаєрів у литковому м'язі реєстрували 60-70\% ПС волокон і близько $30 \%$ ШС волокон. Хоча існують відомості, що силові навантаження 3 великими обтяженнями 3 невеликою кількістю повторень викликають збільшення кількості ШС волокон на 9 \% [19].

Тренування силового i швидкісно-силового спрямувань збільшують у міофібрилах вміст актину, завдяки чому відбувається гіпертрофрія м'язів, яка має назву «гіпертрофія за міофібрилярним типом». Внаслідок такого морфологічного перетворення підвищується не лише силовий, а й швидкісний потенціал м'язів [16]. Тренування силового i швидкісно-силового спрямувань викликають гіпертрофрію не лише ШС, а й ПС волокон, однак цей процес набагато краще проявляється в ШС волокнах. Так, у ШС волокнах тренування силового спрямування збільшують поперечний переріз на 20-50\%, у той час як у ПС волокнах - лише на 5-10\% [10].

Прояв швидкісних можливостей пов'язаний також із вдосконаленням техніки виконання вправ [2, 4]. Раціональні за структурою рухи під час виконання фізичної роботи з максимальною швидкістю залежно від виду спорту забезпечуються роботою певних м'язових груп, що можливо лише за умови високої потужності скорочення цих м'язів.

Важливо відзначити, що потужність м'язового скорочення залежить від вмісту у м'язах АТФ і КрФ, а також від швидкості розщеплення даних речовин під час роботи - чим більший вміст АТФ і КрФ і швидкість їх розщеплення, тим більші потужність скорочення м'язів і силова витривалість [16]. Діапазон вмісту АТФ у людини коливається в межах від 0,25 до 0,4 \%, а КрФ - від 0,2 до $0,55 \%$.

Між добутком сили і швидкості скорочення, які визначають потужність скорочення м'язів, існує так звана «характеристична» залежність, яка полягає у наступному. За правилом Хілла, найбільша сила м'язів (ступінь напруження) може проявлятися лише за умови скорочення в ізо- метричному режимі, коли швидкість скорочення дорівнює нулю, а найвища швидкість скорочення - при напруженні м'язів, що становить 0,2 від індивідуального максимуму сили. Тому збільшення максимальної сили м'язів підвищує швидкість їх скорочення.

Для тренера, який працює зі спринтерами, особливого значення набуває питання про тривалість тренувального процесу від початку силової підготовки до початку морфофуннціональних змін у м'язових волокнах активних м'язових груп, від роботи яких залежить прояв швидкості. Встановлено, що морфоофункціональні зміни в м'язовому апараті під впливом силових тренувань проявляються вже на другому тижні від початку занять, а відчутні адаптаційні перетворення морфологічного, функціонального і біохімічного характеру - після завершення місячного терміну [10].

Отже, оскільки такі морфоорункціональні чинники швидкісних можливостей людини, як співвідношення ШС і ПС волокон, здатність моторних центрів активізувати максимальну кількість рухових одиниць, а також швидкість і частота поширення імпульсів по мотонейронах, генетично детерміновані, основним методичним шляхом покращення швидкості залишається застосування засобів і методів фрізичного виховання, які покращують силу, силову витривалість і швидкість скорочення тих м'язових груп, що забезпечують специфрічну для кожного виду спорту структуру рухів. Біологічною основою збільшення сили і швидкості скорочення м'язів $\epsilon$ посилення синтезу актину, а також вдосконалення алактатної системи енергозабезпечення м'язової роботи. Звільнення енергії в цій системі енергозабезпечення відбувається виключно за рахунок розщеплення макроергів - АТФ і КрФ. Разом з тим такий механізм енергозабезпечення характеризується не лише високою швидкістю звільнення енергії, а й невисокою енергоємністю, що призводить до виснаження ії можливостей вже через 10-12 с від початку роботи. Через це робота максимальної потужності може тривати не більше вказаного часу.

Для підвищення потужності і ємності алактатної системи енергозабезпечення слід застосовувати спринтерські вправи тривалістю 5-6 с із незначним числом повторень (до 10) і нерегламентованими інтервалами відпочинку, достатніми для відновлення АТФ і КрФ, а також вправи силового спрямування. За результатами дослідження В. М. Платонова [11], чотиритижнева спеціалізована силова підготовка висококваліфікованих плавців, спрямована на підвищення 
сили тих м'язових груп, які забезпечують переміщення тіла спортсмена у воді, сприяла збільшенню швидкості плавання на $4 \%$. Під впливом багаторічного тренування із застосуванням спринтерських і силових фрізичних навантажень потужність анаеробної алактатної системи можна збільшити у 2,5 раза [6, 17]. Спринтерські тренування протягом восьми тижнів у бігунів, велосипедистів, плавців здатні збільшувати вміст АТФ і КрФ у скелетних м'язах до $10 \%$, а чотиримісячні важкоатлетичні тренування - зростання АТФ на $18 \%$ і КрФ на 5 \% [20]. Паузи відпочинку між спринтерськими вправами повинні тривати не менше 1,5-2 хв, а при збільшенні тривалості вправ до 10-20 хв. За умов тривалого відпочинку між вправами зменшується обсяг виконаної роботи. Тому для забезпечення достатнього обсягу такої роботи ми пропонуємо застосовувати серійний метод виконання спринтерських вправ (2-4 серії), а між серіями протягом 10-20 хв виконувати роботу, яка сприяє відновленню запасів КрФ до вихідного рівня (стретчинг, вдосконалення техніки, біг, плавання з помірною інтенсивністю тощо).

Мета дослідження - науково обгрунтувати доцільність серійного застосування спринтерських навантажень для підвищення потужності анаеробних алактатних процесів енергозабезпечення плавців на етапі їх попередньої базової підготовки.

\section{Завдання дослідження:}

- вивчити й узагальнити сучасні науково-методичні відомості, що стосуються проблеми вдосконалення швидкості в циклічних видах спорту;

- визначити ефрективність впливу занять із застосуванням спеціальних спринтерських навантажень на фрункціональну і спеціальну фрізичну підготовленість плавців на етапі попередньої базової підготовки.

Методи дослідження: теоретичний аналіз і узагальнення літературних джерел; дослідження потужності анаеробної алактатної

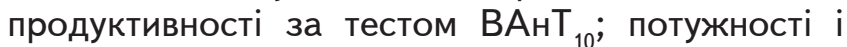
ємності анаеробної лактатної продуктивності за тестами ВАнТ $_{30}$ і МКЗМР відповідно; потужності аеробних процесів енергозабезпечення за тестом V을 тестами В. М. Платонова [12, 13]; тестом, який характеризує кількість пропливання 25-метрових відрізків у зоні анаеробного алактатного режиму енергозабезпечення [14].

Результати дослідження та їх обговорення. У дослідженні брали участь 35 спортсменівплавців чоловічої статі 13-14 років (кваліфрікація на рівні II і III спортивних розрядів), які перебували на етапі попередньої базової підготов- ки четвертого року навчання. Спортивний стаж досліджуваних становив 5-6 років. Способом випадкової вибірки сорормовано дві групи: контрольна (18 осіб) й основна (17 осіб). Між фрункціональними показниками і показниками фрізичної підготовленості спортсменів обох груп вірогідних відмінностей не встановлено ( $>>0,05)$.

Плавці обох груп займалися за навчальною програмою з плавання [8]. Відмінність занять для плавців контрольної та основної груп полягала в тому, що спортсмени основної групи протягом 16 тиж. підготовчого періоду річного макроциклу після розминки тричі на тиждень за рахунок зменшення вправ анаеробного лактатного спрямування виконували чотири серії вправ швидкісного спрямування на відрізках довжиною 25 м в/с. Збільшення кількості занять у такому режимі у тижневому мікроциклі могло б негативно позначитися на розвитку швидкості через неповне відновлення біохімічних і фрункціональних резервів організму [9].

Виконання вправ з максимальною інтенсивністю (за рахунок креатиноросфратного механізму енергозабезпечення) відбувається в межах частоти серцевих скорочень (ЧСС) $150-170$ уд $\cdot$ хв $^{-1}$ [7]. Тому кількість пропливання 25-метрових відрізків з максимально можливою швидкістю в одній серії обмежувалася ЧСС 150-170 уд · хв ${ }^{-1}$ (одразу після пропливання). Перевищення ЧСС позначки 170 уд · хв ${ }^{-1}$ свідчило про перехід креатинфоссратного механізму енергозабезпечення м'язової роботи до роботи за рахунок гліколізу (табл. 1).

Інтервал відпочинку між вправами становив 2-3 хв. Між серіями спортсмени активно відпочивали до 10 хв шляхом застосування компенсаторного плавання в аеробному режимі енергозабезпечення з акцентуванням уваги на техніці, що забезпечувало відновлення АТФ та КрФ, усувало біофрізичні зміни в організмі, а також нормалізувало співвідношення процесів збудження і гальмування, які порушувалися в період відновлення спринтерської плавальної серії [9].

Протягом 16 тиж. занять у плавців контрольної групи результати спеціальних тестів, що характеризують працездатність в зоні алактатного (25 м в/с) та лактатного енергозабезпечення (4 . 50 в/с), залишилися без істотних змін (табл. 2). Разом з тим на 7,1 с вірогідно покращилася працездатність у зоні аеробного енергозабезпечення м'язової роботи.

Крім того, про недостатню ефективність впливу тренувальних занять плавців контрольної групи на швидкість свідчить незмінність протягом 16 тиж. кількості разів пропливання 25-метрових 
ТАБЛИЦЯ 1 - Оцінка енергетичного характеру циклічної роботи за фізіологічними і біохімічними показниками [7]

\begin{tabular}{|c|c|c|c|c|}
\hline $\begin{array}{c}\text { Енергетичний } \\
\text { характер навантаження }\end{array}$ & $\begin{array}{c}\text { чCC, } \\
\text { уд } \cdot \mathrm{xB}^{-1}\end{array}$ & $\begin{array}{c}\text { Споживання } \\
\text { кисню, } \\
\boldsymbol{\pi} \cdot \mathbf{x B}^{-1} \\
\end{array}$ & $\begin{array}{c}\text { Вміст молочної } \\
\text { кислоти в крові, } \\
\text { ммоль · л }\end{array}$ & рН крові \\
\hline Переважно аеробний & до 170 & до 2,5 & до 4 & $7,42-7,30$ \\
\hline $\begin{array}{l}\text { Змішаний аеробно- } \\
\text { анаеробний }\end{array}$ & від 170 до максимальних значень & від 2,5 до максимальних значень & від 4-13 & $7,30-7,20$ \\
\hline Анаеробний гліколітичний & максимальні значення & близько максимальних значень & більше 17 & нижче 7,20 \\
\hline Анаеробний алактатний & $150-170$ & від 2,5 до 4,0 & $4-13$ & $7,30-7,20$ \\
\hline
\end{tabular}

ТАБЛИЦЯ 2 - Результати тестів спеціальної фізичної підготовленості плавців на різних етапах дослідження

\begin{tabular}{|c|c|c|c|c|c|c|}
\hline \multirow{3}{*}{ Показники } & \multicolumn{6}{|c|}{ Значення статистичних показників } \\
\hline & \multicolumn{2}{|c|}{ до початку занять } & \multicolumn{2}{|c|}{$\begin{array}{l}\text { через } 8 \text { тиж. від } \\
\text { початку занять }\end{array}$} & \multicolumn{2}{|c|}{$\begin{array}{l}\text { через } 16 \text { тиж. від } \\
\text { початку занять }\end{array}$} \\
\hline & $\bar{x}$ & s & $\bar{x}$ & s & $\bar{x}$ & s \\
\hline \multicolumn{7}{|c|}{ Контрольна група $(n=18)$} \\
\hline Плавання 800 м вільним стилем, с & 727,2 & 8,9 & 724,8 & 8,8 & 720,1 & $7,6^{*}$ \\
\hline $\begin{array}{l}\text { Плавання } 4 \text { × } 50 \text { м вільним стилем з інтервалом відпочинку } 15 \text { с: } \\
\text { 1-й відрізок } \\
2 \text {-й відрізок } \\
3 \text {-й відрізок } \\
\text { 4-й відрізок }\end{array}$ & $\begin{array}{l}34,5 \\
38,7 \\
41,4 \\
42,3\end{array}$ & $\begin{array}{l}0,6 \\
0,5 \\
1,0 \\
1,4\end{array}$ & $\begin{array}{l}34,3 \\
38,5 \\
41,1 \\
42,0\end{array}$ & $\begin{array}{l}0,5 \\
0,5 \\
1,0 \\
1,4\end{array}$ & $\begin{array}{l}34,1 \\
38,3 \\
41,0 \\
41,9\end{array}$ & $\begin{array}{l}0,5 \\
0,5 \\
0,9 \\
1,3\end{array}$ \\
\hline Плавання 25 м вільним стилем, с & 14,9 & 1,7 & 14,8 & 1,7 & 14,7 & 1,7 \\
\hline \multicolumn{7}{|c|}{ Основна група $(n=17)$} \\
\hline Плавання 800 м вільним стилем, с & 725,0 & 8,6 & 721,6 & 7,1 & 716,3 & $5,3^{*}$ \\
\hline $\begin{array}{l}\text { Плавання } 4 \text { × } 50 \text { м вільним стилем з інтервалом відпочинку } 15 \text { с: } \\
\text { 1-й відрізок } \\
2 \text {-й відрізок } \\
\text { 3-й відрізок } \\
4 \text {-й відрізок } \\
\text { Плавання } 25 \text { м вільним стилем, с }\end{array}$ & $\begin{array}{l}34,3 \\
39,1 \\
42,1 \\
44,2 \\
14,9\end{array}$ & $\begin{array}{l}0,6 \\
0,6 \\
0,7 \\
0,9 \\
1,3\end{array}$ & $\begin{array}{l}34,1 \\
38,6 \\
41,4 \\
43,7 \\
14,23\end{array}$ & $\begin{array}{l}0,6 \\
0,6 \\
0,6 \\
0,9 \\
1,1\end{array}$ & $\begin{array}{l}33,3 \\
37,7 \\
40,7 \\
42,9 \\
13,4\end{array}$ & $\begin{array}{c}0,4 \\
0,6 \\
0,6 \\
0,8 \\
0,9^{*}\end{array}$ \\
\hline
\end{tabular}

* відмінності відносно вихідних даних статистично достовірні $(p<0,05)$

відрізків з максимально можливою швидкістю при ЧСС 150-170 уд · хв ${ }^{-1}$ (табл. 3).

Тренувальні заняття плавців контрольної групи протягом даного періоду не вплинули на потужність аеробних процесів енергозабезпечення за показником $\dot{V} \mathrm{O}_{2} \max$, на потужність анаеробних алактатних (за тестом ВАнТ 10 ) й лактатних (за тестом $\mathrm{BAнT}_{30}$ ) процесів енергозабезпечення, а також на ємність анаеробних лактатних процесів (за тестом МКЗР) енергозабезпечення (табл. 4).

Тренування, які проводилися 3 основною групою, на відміну від спортсменів контрольної групи, суттєво підвищили не лише працездатність у зоні аеробного енергозабезпечення на 8,7 c $(p<0,05)$ за результатом тесту плавання на 800 м вільним стилем, а й швидкість плавців за результатом тесту плавання на 25 м в/с на 1,5 с $(p<0,05)$ (див. табл. 2). Про підвищення працездатності в зоні анаеробного алактатного енергозабезпечення юних плавців свідчить також збільшення кількості разів пропливання 25-метрових відрізків вільним стилем з макси- мально можливою інтенсивністю в межах ЧСС 150-170 уд · хв ${ }^{-1}$ (див. табл. 3).

Заняття, в яких серійно застосовували вправи, спрямовані на розвиток швидкості, не викликали суттєвих змін середніх значень функціональної підготовленості плавців основної групи через

ТАБЛИЦЯ 3 - Кількість пропливання 25-метрових відрізків у зоні анаеробного алактатного режиму енергозабезпечення плавцями на різних етапах дослідження

\begin{tabular}{|c|c|c|c|c|c|}
\hline \multicolumn{6}{|c|}{ Середнє значення кількості пропливання, разів } \\
\hline до початку занять & $\begin{array}{c}\text { через 8 тиж. } \\
\text { від початку занять }\end{array}$ & $\begin{array}{c}\text { через 16 тиж. } \\
\text { від початку занять }\end{array}$ \\
\hline$\overline{\boldsymbol{x}}$ & $\mathrm{s}$ & $\overline{\boldsymbol{x}}$ & $\mathrm{s}$ & $\overline{\boldsymbol{x}}$ & $\mathrm{s}$ \\
\hline \multicolumn{7}{|c|}{ Контрольна група (n = 18) } \\
\hline 2,7 & 0,11 & 2,8 & 0,11 & 3,0 & 0,22 \\
\hline \multicolumn{7}{|c|}{ Основна група (n=17) } \\
\hline 2,91 & 0,2 & 4,0 & 0,2 & 5,09 & $0,1^{*}$ \\
\hline
\end{tabular}

* відмінності відносно вихідних даних статистично достовірні $(\mathrm{p}<0,05)$ 
Спортивна медицина, фізична терапія та ерготерапія № 2, 2021

ТАБЛИЦЯ 4 - Працездатність у зоні аеробного та анаеробного енергозабезпечення плавців на різних етапах дослідження

\begin{tabular}{|c|c|c|c|c|c|c|}
\hline \multirow{3}{*}{ Показники } & \multicolumn{6}{|c|}{ Значення статистичних показників } \\
\hline & \multicolumn{2}{|c|}{ до початку занять } & \multicolumn{2}{|c|}{ через 8 тиж. від початку занять } & \multicolumn{2}{|c|}{ через 16 тиж. від початку занять } \\
\hline & $\bar{x}$ & s & $\bar{x}$ & $\mathrm{~s}$ & $\bar{x}$ & $\mathbf{s}$ \\
\hline \multicolumn{7}{|c|}{ Контрольна група ( $\mathrm{n}=18)$} \\
\hline 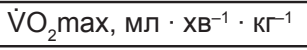 & 41,56 & 0,77 & 42,26 & 1,12 & 43,41 & 1,11 \\
\hline $\mathrm{BaHT}_{10}, \mathrm{~K} \Gamma \mathrm{M} \cdot \mathrm{xB}^{-1} \cdot \mathrm{K}^{-1}$ & 31,8 & 1,95 & 33,9 & 1,95 & 34,8 & 1,62 \\
\hline $\mathrm{BaHT}_{30}, \mathrm{KгM} \cdot \mathrm{XB}^{-1} \cdot \mathrm{K}^{-1}$ & 28,8 & 0,87 & 30,0 & 0,87 & 31,3 & 0,97 \\
\hline МКЗМР, кгм $\cdot \mathrm{xB}^{-1} \cdot \mathrm{K}^{-1}$ & 26,01 & 0,95 & 26,47 & 0,87 & 26,85 & 0,87 \\
\hline \multicolumn{7}{|c|}{ Основна група $(\mathrm{n}=17)$} \\
\hline $\mathrm{V}_{2} \max , \mathrm{M} \cdot \cdot \mathrm{xB}^{-1} \cdot \mathrm{Kr}^{-1}$ & 42,69 & 0,97 & 43,95 & 0,64 & 44,56 & $0,63^{*}$ \\
\hline 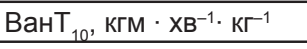 & 39,3 & 1,95 & 42,3 & 1,62 & 44,4 & $1,30^{*}$ \\
\hline $\mathrm{BaHT}_{30}, \mathrm{~K} \Gamma \mathrm{M} \cdot \mathrm{xB}^{-1} \cdot \mathrm{K}^{-1}$ & 35,8 & 1,19 & 37,2 & 1,41 & 39,3 & $0,97^{*}$ \\
\hline МКЗМР, кгМ $\cdot \mathrm{XB}^{-1} \cdot \mathrm{K}^{-1}$ & 26,33 & 0,77 & 27,31 & 0,99 & 28,88 & 0,84 \\
\hline
\end{tabular}

* відмінності відносно вихідних даних статистично достовірні $(p<0,05)$

вісім тижнів від початку занять. Проте через 16 тиж. вірогідно підвищилися можливості спортсменів забезпечувати м'язову роботу за рахунок метаболічних процесів, які характеризують не лише потужність аеробних процесів енергозабезпечення, а й потужність анаеробних алактатних і лактатних процесів (див. табл. 4). Так, середнє значення відносної величини $\dot{\mathrm{V} O} \max$ зросло на 4,5\%, ВАнт 10 - на 15,2 \%, а ВАнТ $_{30}-$ на $9,8 \%$ ( $p<0,05)$. Такі тренування не викликали погіршення рівня фрізичної підготовленості юних плавців за тестами, які характеризують аеробну й анаеробну (лактатну) продуктивність організму, позитивно впливаючи на анаеробну алактатну продуктивність.

\section{Висновки}

1. Узагальнення науково-методичної інфрормації свідчить про наявність двох груп морфофункціональних чинників, які визначають швидкісні можливості спортсменів. Перша - генетично детерміновані, що не піддаються вдосконаленню шляхом застосування фрізичних тренувань (співвідношення ШС і ПС волокон, здатність до активізації моторними центрами рухових одиниць,

\section{Література}

1. Биохимия [Biochemistry]. Edited by VV Menshikov, NI Volkov. Moscow: Fizkultura i sport, 1986. 384 p.

2. Вайцеховский СМ. Тренировка в среднегорье - мощный резерв повышения спортивних результатов [Training in mid-altitude mountains is a powerful reserve for improving sports results]. Науч.-спорт. вестн. 1986; 2: $19-21$.

3. Верхошанский ЮВ. На пути к научной теории и методологии спортивной тренировки [Towards a scientific theory and methodology of sports training]. Теория и практика физической культуры. 1988; 2: 21-7.

4. Верхошанский ЮВ. Основы специальной физической подготовки спортсменов [Fundamentals of special physical training for athletes]. Москва: Физкультура и спорт, 1988. 326 с максимально швидко поширювати імпульси по мотонейронах). Друга група - генетично не детерміновані чинники, на які можна впливати шляхом застосування фрізичних вправ силового, швидкісно-силового і спринтерського спрямування за рахунок підвищення в міофібрилах вмісту актину й удосконалення анаеробних алактатних процесів енергозабезпечення м'язової роботи.

2. Виконання в підготовчий період річного макроциклу на етапі попередньої базової підготовки тричі на тиждень спринтерських вправ (тривалістю до 10 с, з інтервалом відпочинку між вправами близько 2 хв) серійним метод (чотири серії, з інтервалом активного відпочинку між серіями 10-15 хв) позитивно впливає на розвиток швидкості юних плавців за рахунок підвищення потужності анаеробних алактатних процесів енергозабезпечення. Для забезпечення роботи в зоні анаеробного алактатного метаболізму і попередження переходу креатинфросфратного механізму енергозабезпечення на лактатний кількість повторень спринтерських вправ обмежується ЧСС, що не перевищує 170 уд $\cdot \mathrm{xв}^{-1}$.

5. Волков ЛВ. Теория и методика детского и юношеского спорта [Theory and methodology of children's and youth sports]. Киев: Олимп. лит. 2002. 296 C.

6. Волков НИ. Биохимия мышечной деятельности [Biochemistry of muscle activity]. Киев: Олимп. лит., 2000. 504 с.

7. Макарова ГА. Спортивна медицина [Sports medicine]. Москва: Coветский спорт, 2008. 480 с.

8. Навчальна програма для дитячо-юнацьких спортивних шкіл, спеціалізованих дитячо-юнацьких шкіл олімпійського резерву, шкіл вищої спортивної майстерності [Curriculum for children and youth sports schools, specialized children and youth schools of the Olympic reserve, schools of higher sportsmanship] / Міністерство України у справах молоді та спор- 
ту, Республіканський науково-методичний кабінет, Федерація плавання України; уклад.: КП. Сахновський. Киев: Молодь, 1995. 91 с.

9. Платонов ВН. Плавание [Swimming]. Киев: Олимп. лит, 2000. $495 \mathrm{c}$

10. Платонов ВН. Система подготовки спортсменов в олимпийском спорте. Общая теория и ее практические приложения [The system of training athletes in Olympic sports. General theory and its practical applications]. Киев: Олимп. лит., 2004. 808 с.

11. Платонов ВН. Общая теория подготовки спортсменов в Олимпийском спорте [General theory of training athletes in Olympic sports]. Киев: Олимп. лит., 1997.584 с.

12. Спортивное плавание: путь к успеху [Sports swimming: the path to success ] / под общ. ред. ВН. Платонова. Киев: Олимп. лит., 2012. Кн. 1. $544 \mathrm{c}$.

13. Спортивное плавание: путь к успеху [Sports swimming: the path to success] / под общ. ред. ВН. Платонова. Киев: Олимп. лит., 2012. Кн. 2. $480 \mathrm{c}$.

14. Фурман Ю, Грузевич І. Вдосконалення функціональної підготовленості плавців 13-14 років на етапі попередньої базової підготовки шляхом застосування методики ендогенно-гіпоксичного дихання та стимуляції анаеробних алактатних процесів енергозабезпечення [In addition to the functional preparation of sailors of 13-14 years at the stage of the frontal basic preparation, the method of endogenous-hypoxic dysfunction and stimulation of anaerobic alactate processes of energy safety]. Спортивний вісник Придніпров'я. 2013; 13: 121-5.

15. Шиян Б. М. Теорія і методика фізичного виховання школярів. Частина 1 [Theory and methodology of the physical education of schoolchildren. Part 1]. Тернопіль: Навчальна книга - Богдан, 2002. 248 с.

16. De Vries HA, Housh TI. Physiology of Exercise. Madison Wisconsin: WCB Brown and Benchmark Publ., 1994. 636 p.

17. Di Prampero PE. The energetics of running. Endurance in Sport. 1992. P. $542-49$.

18. Gollnick PD, Timson BF, Moore RL, Riedy M. Muscular enlargement and number of fibers in skeletal muscles of rats. J. Appl. Physiol. 1981;50(5).93643.doi: 10.1152/jappl.1981.50.5.936

19. Gonyea WJ, Sale DG, Gonyea F. B. et al. Exercise induced increases in muscle fiber number. Europ. J. Appl. Physiol. 1986; 55: $137-41$ https://doi. org/10.1007/BF00714995

20. Spriet LL. Anaerobic metabolism during high-intensity exercise. Exercise metabolism. Human Kinetics, 1999. 1-40.

21. Timson BF, Bowlin BK, Dudenhoeffer GA, George JB. Fiber number area, and composition of mouse soleus muscle following enlargement. J. Appl. Physiol. 1985;58 (2):619-24. doi: 10.1152/jappl.1985.58.2.619. PMID: 3980364.

22. Wilmore JH, Costill DL. Physiology of sport and exercise. Champaign Illinois: HumanKinetics, 2004. 726 p.

dok.furman@gmail.com

mzugrava@gmail.com

gruzevichirina@gmail.com

Надійшла 31.08.2021 